Humanistika: Jurnal Keislaman

Vol. 8 No. 1 2021. ISSN (Print): 2460-5417 ISSN (Online): 2548-4400

DOI: https://doi.org/10.36835/ humanistika.v8i1.757

\title{
IMPELEMENTASI PEMBISAAN MEMBACA JUZ AMMA \\ UNTUK MEMBENTUK KARAKTER RELIGIUS \\ PESERTA DIDIK
}

\author{
Fahmi Ikrom \\ IAI Syarifuddin Lumajang \\ Fahmi221098@gmail.com \\ Syamsul Arifin \\ IAI Syarifuddin Lumajang \\ Syamsul3404@gmail.com
}

\begin{abstract}
Abstrak
Penelitian ini dilatarbelakangi dengan keringnya karakter religius pada kalangan remaja yang disebabkan oleh pesatnya perkembangan teknologi saeperti sekarang ini yang berdampak kepada kalangan remaja mereka lebih senang bermain gadget, dampaknya para remaja kurang terampil dalam membaca Al-Qur'an, bahkan ada minoritas dari mereka yang belum bisa membaca Al-Qur'an dengan baik dab benar sesuai kaidah tajwid. Sebagai upaya membentuk karakter religius peserta didik di pada zaman sekarang ini, MA AL-kholafiyah melaksanakan pembiasann membaca Juz Amma. Adapun fokus penelitian ini ialah untuk mengetahui implementasi pembiasaan membaca Juz Amma untuk membentuk karakter religius peserta didik di MA Al-Kholafiyah, faktor pendukung dan penghambatnya serta bagaimana implikasinya. Metode yang dipakai dalam penelitian ini adalah metode kualitatif deskriptif. Hasil analisis data berupa pemaparan tentang situasi yang diteliti dan disajikan dalam bentuk uraian naratif. Dalam pengumpulan data, peneliti menggunakan teknik wawancara, observasi dan dokumentasi.
\end{abstract}

Kata kunci: Pembiasaan, Membaca Juz Amma, Karakter Religius. 


\section{Impelementasi pembisaan membaca juz amma}

\section{Untuk membentuk karakter religius peserta didik}

\section{PENDAHULUAN}

Dalam pendidikan, tidak hanya materi pelajaran saja yang dajarkan dan diterapkan kepada peserta didik tetapi juga upaya untuk membentuk karakter bagi peserta didik. hal ini penting karena bulding character atau pembentukan karakter peserta didik merupakan tujuan pendidikan nasional yang menyatakan bahwa: Pendidikan nasional berfungsi mengembangkan kemampuan dan membentuk karakter serta peradaban bangsa yang bermartabat dalam rangka mencerdaskan kehidupan bangsa. yang mana telah dinyatakan dan ditetapkan dalam UU No 20 tahun 2003 tentang sistem pendidikan nasional pada pasal 3. Pendidikan nasional bertujuan untuk berkembangnya potensi peserta didik agar menjadi manusia yang beriman dan bertaqwa kepada Tuhan yang Maha Esa, berakhlak mulia, sehat, berilmu, cakap, kreatif, mandiri dan menjadi warga negara yang demokratis serta bertanggungjawab. ${ }^{1}$

Pendidikan karakter bukanlah pendidikan yang haya bertukar informasi saling belajar mengajar, tentang sesuatu yang benar atau salah. Namun juga perlu menanamkan nilai dan menjadikannya sebagai kebiasaan atau kecenderungan yang dilakukan secara konsisten terus-menerus oleh peserta didik. Jadi, pendidikan karakter merupakan upaya untuk menyesuaikan kemampuan siswa pada umumnya, dimana tidak hanya

1 Undang-Undang Republik Indonesia Nomor 20 Tabun 2003 Tentang SISDIKNAS (Bandung: Citra Umbara, 2006).

Humanistika: Vol.8 No.1 2022 
condong pada ranah intelektual kognitif, namun juga pada ranah psikomotor dan juga ranah afektif. ${ }^{2}$

Dalam membentuk pribadi peserta didik, sikap religius harus dikembangkan secara maksimal. Pendididik di sekolah serta wali peserta didik memiliki peranan dan. tanggungjawab yang besar dalam menciptakan pribadi peserta didik yang religius. Dalam agama Islam. mengharuskan bahwa. pendidikan agama harus diajarkan sejak anak lahir, yang diharapkan nantinya anak memiliki karakter religius. ${ }^{3}$

Pribadi dan sikap religius adalah sikap peserta didik yang identik dengan hubungan manusia dengan Tuhan. Karakter religius sangat penting untuk ditanamka dan dikembangkan kepada peserta didik dalam membangun perkataan, pikiran, serta perilaku peserta didik yang diusahakan untuk selalu berdasar pada nilai dan norma ketuhanan yang berdasar pada ajaran agama yang dianut. Jadi, pendidkan agama yang dianut pesera didik benar-benar dihayati, difahami dan dipraktikkkan setiap hari. ${ }^{4}$

Penelitian ini dilatarbelakangi dengan keringnya karakter religius pada kalangan remaja yang disebabkan oleh pesatnya perkembangan teknologi seperti sekarang ini yang berdampak kepada kalangan remaja yang

2 A.Rodli Makmun. Pembentukan Karakter Berbasis Pendidikan Pesantren (Studi Di Pondok Pesantren Tradisional Dan Modern Di Kab.Ponorogo) (Ponorogo: Stain Ponorogo Press, 2014), Diakses dari https://jurnal.iainponorogo.ac.id//15 september 2021]

3 Ngainun Na'im.Character Building : Optimalisasi Peran Pendidikan Dalam Pengembangan Ilmu \& Pembentukan Krakter Bangsa (Jogjakarta:Ar-Ruzz Media,2012) ${ }^{4}$ Akhmad Muhaimin Azzet,Urgensi Pendidikan Karakter Di Indonesia: Revitalisasi Pendidikan Karakter Terhadap Keberhasilan Dan Kemajuan Bangsa (Jogjakarta: Ar- Ruzz Media, 2013).

Humanistika: Vol.8 No.1 2022 


\section{Impelementasi pembisaan membaca juz amma \\ Untuk membentuk karakter religius peserta didik}

lebih senang bermain gadget, yang mana hali ini mengakbatkan mereka kurang terampil dalam membaca Al-Qur'an, bahkan ada minoritas dari peserta didik yang belum bisa membaca Al-Qur'an secara lancar. mereka juga pada umumnya akan ikut pada budaya barat dalam bergaul dan ketika berbicara dengan orang lain atau dengan individu yang lebih sepuh. Hal ini sejalan dengan pendapat guru MA Al-Kholafiyah Tekung Lumajang yang menerangkan bahwasanya ada dari beberapa peserta didik yang belum lancan bacaan Al-Qur'an, kurang perhatian pada tata tertib sekolah, minimnya sikap disiplin, minimnya kesadaran peserta didik pada kewajiban ibadah. Selain itu, serta minimnya perhatian peserta didik terhadap keadaan lingkungan sekitar.

Sebagai upaya dalam menyikapi hal ini maka dibentuklah kegiatan pembiasaan membaca Jur. Amma Sebagai bentuk usaha yang dilakukan MA Al-Kholafiyah Tekung Lumajang dalam meminimalisir permasalahan yang muncul tersebut dan untuk membentuk karakter peserta didik. Peneliti tertarik untuk meneliti kegiatan pembisaaan membaca membaca Juz. Amma ini. Karena dengan adanya pembisaaan religius ini diharapkan dapat membentuk karakter peserta didik yang berjiwa Qur'ani, serta Berkblakul Karimah Ablussunnah Wal Jamaah. Dalam upaya membentuk karakter peserta didik, diperlukan upaya yang konsisten dan istoqomah. Salah satu cara untuk membentuk dan mengembengkan kepribadian religius peserta didik adalah dengan menggunakan metode pembiasaan. Membentuk karakter dan kepribadian peserta didik menjadi individu yang lebih baik merupakan upaya yang tidak mudah dan tdak dapat terbentuk secara instan seperti Humanistika: Vol.8 No.1 2022 
membalikkan telapak tangan. Upaya tersebut harus dipersiapkan secara sungguh-sungguh dan berkesinambungan agar tujuan perubahan yang ideal dapat tercapai. ${ }^{5}$

Pada jurnal penelitian ini akan dibahas tentang bagaimana implementasi pembisaaan membaca Juz Amma di MA Al-Kholafiyah Tekung Lumajang, faktor-faktor apa saja yang mendukung dan menghambat dalam pelaksanaan pembisaaan membaca Juz. Amma di MA Al-Kholafiyah Tekung Lumajang dan bagaimana implikasi dari pembisaaan membaca Juz. Amma di MA Al-Kholafiyah Tekung Lumajang. Sehingga tujuan dari penelitian ini adalah untuk mengetahui bagaimana implementasi pembiasaan membaca Juz. Amma untuk membentuk karakter religius peserta didik di MA Al-Kholafiyah, apa saja faktor pendukung dan penghambatnya dan bagaimana implikasinya.

\section{Kajian Konseptual}

\section{Metode Pembiasaan}

Dari segi etimologi, pembisaaan mempunyai asal kata "biasa" yang artinya seperti sedia kala, merupakan hal yang tidak bisa terpisahkan dari kehidupan sehari-hari. Pembisaaan adalah suatu upaya yang mempunya kecenderungan untuk membangun lingkungan sebagai awal dari munculnya karakter dan kepribadian individu, yang cenderung selalu ditonjolkan oleh individu sebagai proses penanaman norma-norma lingkungan agar

5 Ridwan.Abdullah Sani dan Muhammad Kadri.Pendidikan Karakter (Jakarta: Bumi Aksara, 2016), 7.

Humanistika: Vol.8 No.1 2022 


\section{Impelementasi pembisaan membaca juz amma}

\section{Untuk membentuk karakter religius peserta didik}

diperoleh perkembangan dan kemajuan karakter kepribadian seseorang yang ideal dan lebih baik.

Metode pembiasaan bisa menggunakan perintah, tauladan, pengalaman, ataupun menggunakan reward penghahrgaan dimana hal ini bertujuan agar supaya peserta didik memperoleh kepribadian dan kebisaaan perbuatan baru yang lebih baik dan positif, artinya mereka mempuya karakter yang selaras dengan norma serta nilai moral yang berlaku, baik yang bersifat religi ataupun tradisional dan kultural. Jadi, metode pembiasaan adalah proses pembentukan kebisaaan baru serta perbaikan kebisaaan yang sudah ada. Membentuk karakter kepribadian peserta didik melalui metode pembisaaan bisa dilaksanakan dengan cara: 1) Rutin, yaitu pembisaaan dilakukan secara teratur dan terjadwal, contohnya; berjamaah, upacara, tatatertib, dan piket kebersihan. 2) Spontan, yaitu pembisaaan yang dilakukan tanpa direncanakan terlebih dahulu, contohnya; perilaku memberi salam, membuang sampah pada tempatnya, antri, 3) Keteladanan, yaitu kebiasaan baik yang dilakukan pada kegiatan sehari-hari, contohnya; berpakaian rapi, berbahasa yang baik, serta berbuat baik. ${ }^{6}$

Dengan melaksanakan metode pembisaaan, peserta didik akan cenderung terhadap pembiasaan yang sudah dibisakan pada peserta didik tersebut. Kecenderungan ini akhirnya menimbulkan kebisaaan sehingga menjadikan kepribadian yang lekat terhadap karakter peserta didik. Jika metode pembisaaan ini sudah di implementasikan dengan baik dan 
konsisten secara terus menerus, alhasil peserta didik akan mampunya kepribadian yang baik pula serta tidak mustahil kepribadian mereka juga akan dijadikan suri teladan bagi orang lain. Jadi dapat disimpulkan metode pembisaaan ini sangat efektif dalam memebentuk karakter dan kepribadian peserta didik. ${ }^{7}$

\section{Memebaca Al-Qur'an}

Mampercayai, membaca, mengamalkan, memelihara, Belajar dan mengajarkan Al-Qur'an merupakan sesuatu yang wajib bagi setiap orang yang beriman untuk dilaksanakan. Melalui pendidikan Al-Qur'an, peserta didik akan mencapai tujuan yang diharapkan yaitu terbentuknya karakter baik dan akhlak mulia sebagai tujuan tertinggi dari pendidikan Islam. Dengan memabaca Al-Qur'an maka seseorang tersebut telah melakukan paling utamanya ibadah, seperti hadits Rasulullah :

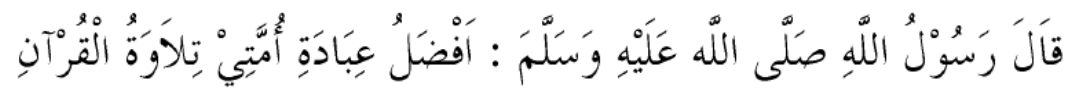

Rasulullah SAW bersabda: "ibadah umatku yang paling utama adalah membaca Al-Qur'an ."

Menurut para ulama' membaca dan memahami Al-Qur'an dapat menguatkan kualitas keimanan seseorang serta melindungi diri dari perbuatan-perbuatan jahat dan sia-sia. Al-Qur'an merupakan pedoman hidup manusia. Manusia yang senantiasa berpegang teguh terhadap AlQur'an akan tahu bagaimana Al-Qur'an memberi aturan dan batasan.

${ }^{7}$ Amirulloh Syarbini, Model Pendidikan Karakter dalam Keluarga (Jakarta:Elex Media Komputindo, 2014) 62-63.

Humanistika: Vol.8 No.1 2022 


\section{Impelementasi pembisaan membaca juz amma}

Untuk membentuk karakter religius peserta didik

Dengan sering membaca dan memahami Al-Qur'an seseorang dapat membedakan mana yang haq dan mana yang batil, mana perbuatan yang diperintah dan mana perbuatan yang dilarang oleh Allah SWT, sehingga ia dapat menghindari sesuatu yang tidak bermanfaat bagi dirinya. ${ }^{8}$

Adapun keutamaan dan manfaat belajar dan mengajarkan Al-Quran adalah sebagai berikut: 1) Seseorang yang belajar dan mengajarkan Al-Quran adalah sebaik-baiknya orang dan nanti akan mendapatkan balasan pahala yang berlipat ganda dari Allah. 2) Orang-orang yang membaca dan mengamalkan al-Quran yaitu orang-orang yang beruntung dan tidak akan merugi. 3) Selain merupakan amal kebajikan, memperbanyak membaca alQuran bisa membebaskan seseorang dari sentuhan api neraka, karena kelak pada hari kiamat al-Quran akan memberi syafa'at. 4) Membaca al-Quran adalah suatu ibadah yang lebih utama bagi umat Muhammad saw. ${ }^{9}$

\section{Karakter Religius}

Karakter bisa dipahami sebagai tabiat, watak, sifat-sifat kejiwaan, akhlak atau budi pekerti yang membedakan seorang dengan yang lain. ${ }^{10}$ Dalam pengertianyya, watak adalah sifat seseorang yang berpengaruh pada segenap pikiran dan perbuatannya. Karakter cenderung mangacu kepada (attitudes) sikap, (behaviors) perilaku, (motivations) motivasi, serta (skills)

${ }^{8}$ Muhammad Alim,Pendidikan Agama Islam,(Bandung:Remaja Rosdakarya),2011,h.181

9 Rosniati Hakim,"Pembentukan Karakter Peserta Didik melalui Pendidikan Berbasis Alqur'an,” Jurnal Pendidikan Karakter,No.2(Juni 2014), $127 . \quad$ Diakses Dari https://journal.uny.ac.id// [15 September 2021]

${ }^{10}$ Abdul Majid dan Andayani, Pendidikan Karakter Prespektif Islam (Bandung: PT Rosda Karya, 2013), 11.

Humanistika: Vol.8 No.1 2022 
ketrampilan. Seseorang yang berkarakter adalah seseorang yang berkepribadian, berperilaku, bersifat, dan berwatak. Seseorang yang berkarakter baik cenderung berpikiran baik, berperasaan yang baik, dan berperilaku baik. Dengan karakter yang baik maka seorang akan mempunyai Soft skills yang baik pula, Soft skills adalah keterampilan seseorang dalam berhubungan dengan orang lain (termasuk dengan dirinya sendiri). Soft skill memmpunyai tiga aspek kecakapan yaitu: 1) kecakapan mengenal diri biasa disebut dengan personal skill yang meliputi: penghayatan diri sebagai makhluk tuhan YME, anggota masyarakat dan warga negara, mensyukuri dan menyadari kelebihan dan kekurangan, sekaligus menjadikannya sebgai modal dalam meningkatkan dirinya sebagai pribadi yag lebih baik. 2) kecakapan berpikir rasional yang meliputi : kecakapan menggali informasi dan mengambil keputusan, kecakapan memecahkan masalah secara kreatif. Dan ke 3) kecakapan sosial yang meliputi : kecakapan komunikasi dan empati, bekerjasama, memimpin dan kecakapan memberikan pengaruh. ${ }^{11}$

Menurut Ridwan, yang diambil oleh Aisyah M. Ali pada bukunya yamg memebahas kaitanyya dengan "Pendidikan Karakter" dijelaskan secara spesifik tahap-tahap dalam membentuk karakter kepibadian peserta didik, yaitu: pertama (Knowing the good) Mengetahui kebajikan, artinya peserta didik bisa mengetahui hal yang baik dan buruk, faham terhadap tindakan yang harus diambil serta bisa mendahulukan ha-hal yang baik. Kedua (Feeling

11 Moh Ahsanulkhaq, "Membentuk Karakter Religius Peserta Didik Melalui Metode Pembisaaan”, Jurnal Prakarsa Paedagogia, Vol.2 No. 1,(2019). Diakses dari https://jurnal.umk.ac.id [15 September 2021)

Humanistika: Vol.8 No.1 2022 


\section{Impelementasi pembisaan membaca juz amma}

\section{Untuk membentuk karakter religius peserta didik}

the good) Merasakan kebajikan, artinya peserta didik bisa merasakan efek perbuatan baik yang dilakukannya sehingga tumbuh kecintaan untuk senantasa melakukan perbuatan baik dan secara tidak langsung membentuk sikap menghindari perbuatan jahat. dan yang Ketiga (Active the good) Melaksanakan kebajikan, artinya peserta didik bisa dan terbisaa berperilaku baik. Pada tahapan ini peserta didik dilatih untuk terbisaa berperilaku baik, tanpa terbisaa mengaalkan perbuatan baik yang telah dipelajari dan dirasakan sebagai kebaikan maka tidak aka ada artinya. ${ }^{12}$

Religius merupakan sebuah karakter yang erat hubungannya dengan tuhan. Dimana hal ini menunjukkan bahwasanya pikiran, perkataan dan tindakan seseorang yang dilakukan sehari-hari selalu berdasar pada nilai-nilai ketuhanan ataupun ajaran agamanya. Religius marupakan sikap dan perilaku seseorang yang patuh dalam mengamalkan ajaran agama yang dianutnya, bersikap toleransi pada pelaksanaan ibadah yang dilakukan agama lain, serta hidup rukun dengan pemeluk agama lain. Dalam agama islam menjadi karakter yang religius berarti seseorang menjadi pribadi yang senag melakukan ibadah, mengerjakan sunnah dan patuh dalam menjalankan syariat agama islam. ${ }^{13}$

\section{Metode}

12 Aisyah M.Ali, Pendidikan Karakter: Konsep dan Implementasinya (Jakarta: Kencana, 2018)

${ }^{13}$ Nursalam, Model Pendidikan Karakter (Serang:CV AA Rizky.2020)

Humanistika: Vol.8 No.1 2022 
Pada juranal penelitian ini peneliti menggunakan jenis penelitian kualitatif deskriptif. Diman hasil data berupa pemaparan tentang situasi dan kondisi yang diteliti dan disajikan dalam bentuk uraian naratif deskriptif. Pada tehnik pengumpulan data, peneliti menggunakan teknik: Pertama Wawancara, peneliti memakai teknik wawancara bebas terpimpin, dimana peneliti bebas bertanya apa saja yang ingin peneliti ketahui, tetapi pertanyaan tersebut harus sesuai dengan pedoman wawancara dan mempermudah narasumber dalam memberi jawaban secara rinci. Kedua Observasi, peneliti melaksanakan kegiatan observasi dengan meihat langsung keadaan di MA Al-Kholafiyah Tekung yang berkaitan dengan fokus penelitian yang dilakukan. dan Ketiga Dokumentasi. Peneliti menggunakan teknik dokumentasi dengan melihat dokumen yang berkaitan dengan fokus penelitan yang dilakukan. Peneliti menggunakan data reduction, data display, dan conclusion drawing/verification dalam Aktivitas analisis data. Penelitian ini dilaksanakan di MA Al-Kholafiyah Tekung Lumajang. Sumber data primer dalam penelitian ini adalah peserta didik dan guru MA AlKholafiyah Tekung Lumajang.

\section{Hasil dan Pembahasan}

Implementasi pembisaaan membaca Juz Amma di MA Al-Kholafiyah 


\section{Impelementasi pembisaan membaca juz amma}

Untuk membentuk karakter religius peserta didik

Pembentukan karakter dari mata pelajaran saja tidaklah cukup untuk digunakan sebagai satu satunya upaya membentuk karakter peserta didik yang bernilai religius apalagi membentuk karakter peserta didik yang senang membaca Al-Quran. Untuk itu, bentuk usaha yang dilakukan oleh MA AlKholafiyah tekung untuk membentuk serta meningkatkan sikap dan karakter religius peserta didik yaitu dengan cara memberikan kegiatan pembisaaan positif, yaitu dengan menmbentuk lingkungan yang religious melalui pembisaaan membaca Juz Amma. ${ }^{14}$ Pembisaaan ini bukan hanya untuk membentuk peribadian siswa agar lebih baik, tetapi juga menjadi pribadi yang senag membaca Al-Quran. Pembisaann ini dilaksanakan secara konsisten dan terus menerus sehingga tujuan dari pembisaaan tersebut dapat dirasakan serta kemudian dapat menjadi kebisaaan yang sulit ditinggalkan dalam kehidupan sehari hari. selain itu juga ini akan menimbulkan citra baik dari masyarakat jika ada lulusan madrasah yang bagus dalam membaca AlQuran. Hal ini tidak telepas dari tujuan yang diharapkan dan juga visi misi sekolah yaitu terwujudnya siswa yang beriman. Beraqidah, berilmu, beramal, berakhlakul karimah ablussunnah wal jamaah. ${ }^{15}$

Bentuk usaha yang dilakukan MA Al-Kholafiyah Tekung dalam membentuk karakter dan kepribadian peserta didik yang religious adalah dengan memberikan pembasaan yang positif, seperti membangun lingkungan bernuansa religi dengan metode pembiasaan membaca Juz Amma. Kegiatan pembaisaan membaca Juz. Amma yang sudah

\footnotetext{
${ }^{14}$ Wawancara ibu ida(Kepala Sekolah)

${ }^{15}$ Dokumen Visi Misi Madrasah Al-Kholafiyah Tekung Lumajang

Humanistika: Vol.8 No.1 2022
} 
diimplementasikan di MA Al-Kholafiyah Tekung ini tidak terlepas dari tujuan yang diharapkan. Untuk itu, implementasi metode pembiasaan ini dilaksanakan secara berkesinambungan dan rutin, agar tujuan dari implementasi pembiasaan membaca Jur. Amma ini bisa dirasakan di kehidupan sehari-hari dan kemudian bisa dijadikan kebiasaan peserta didik yang sulit dabaikan dikemudian hari. ${ }^{16}$ implementsi pembiasaan membaca Juz Ama ini adalah bentuk usaha yang dilakukan untuk merealisasikan tujuan dari Pendidikan Nasional tentang Sistem Pendidikan Nasional pada Pasal 3 yang mana ada pada Undang-undang Sisdiknas No. 20 Tahun 2003 yakni untuk menanamkan pribadi manusia yang berakhlak mulia.

Dalam pelaksanaannya pembacaan Juz. Amma ini dilakukan setelah jam pelajran terakhir, setelah pembelajran setiap wakil kelas akan mengambil Juz Amma di kantor, kemudian peseta didik membaca selama 15 menit dimulai dari berakhirnya jam pelajaran terakhir yaitu pukul 11.30 WIB sampai 11.45. pembisaaan ini dilakukan di semua kelas mulai, mulai dari sepuluh sampai duabelas baik itu kelas IPS dan IPA. Jadi pembisaaan membaca Juz. Amma ini diwajibkan bagi seluruh siswa. Agar suapaya tertib, Pelakasan dilakukan di setiap kelas agar supaya siswa tidak pulang terlebih dahulu, hal ini membuat siswa disiplin pulang dan istiqomah dalam melakukan hal yang baik. ${ }^{17}$

${ }^{16}$ Amirulloh Syarbini. Model Pendidikan Karakter dalam Keluarga (Jakarta: Elex Media Komputindo, 2014).

${ }^{17}$ Wawancara ibu ida (Kepala Sekolah)

Humanistika: Vol.8 No.1 2022 


\section{Impelementasi pembisaan membaca juz amma}

Untuk membentuk karakter religius peserta didik

Tidak hanya membaca saja peresta didik di MA Al-Kholafiyah juga diwajibkan untuk menghafal seluruh Juz. Amma atau juz 30. dalam hal ini peseta didik meyetorkan hafalan kepada guru pembimbing beberapa surat dengan cara di cicil sehingga sebelum lulus yaitu tahun terakhir di kelas duabelas peserta didik sudah menghafal Juz. Amma/juz 30. Peserta didik wajib mentetorkan hafalan mulai dari tahun pertama mereka masuk sekolah. Jadi, mereka mempunyai waktu kurang lebih tiga tahun untuk menuntaskan hafalan Jur. Amma yang diwajibkan. Hafalan ini juga menjadi syarat nantinya untuk mendapatkan ijazah saat mereka lulus nanti. ${ }^{18}$

Pembiasaan membaca serta kewajiban menghafal Juz Amma bertujuan sebagai bekal bagi peserta didik saat dirumah, ataupun kelak ketika mereka saat berkeluarga dan bermsyarakat, banyak manfaat bagi mereka yang bisa bahkan hafal Jur. Amma. Hal ini juga akan menjadikan luusan dari Madrasah Aliyah Al-Kholafiyah menjadi lulusan yang berkarakter religius, terbiasa membaca dan mengamalkan Al-Qur'an.

Jadi implementasi dari pembiasaan membaca Juz, Amma ini pun telah sesuai dengan cara-cara yang telah para ahli paparkan yaitu: 1) Rutin, pembisaan yang dilakunak harus terjadwal da dilalukan secara terus menerus. Sehiangga terbentuk karakter peserta didik yang istiqomah dan 2) keteladanan yaitu memebentuk karakter peserta didik harus dengan perilaku teladan dengan perbuatan baik, membaca Juz. Amma merupakan perilaku yang mencerminkan keteladanan karena membaca Juz. Amma berarti peserta 
didik membaca Al-Quran, dimanan membaca Al-Quran merupakan ibadah yang diutamakan oleh Rasulullah dan mempunyai banyak manfaat.

Dengan melakukan pembiasaan membaca Juz Amma ini secara terus menerus, peserta didik telah melakukan tahapan dalam pembentukan karakter Menurut Ridwan, yang diambil oleh Aisyah M. Ali pada bukunya yamg memebahas kaitanyya dengan "Pendidikan Karakter" dijelaskan secara spesifik tahap-tahap dalam membentuk karakter kepibadian peserta didik, yaitu: pertama Knowing the good atau Mengetahui kebajikan, artinya peserta didik bisa mengetahui hal yang baik dan buruk, faham terhadap tindakan yang harus diambil serta bisa mendahulukan ha-hal yang baik. Kedua Feeling the good atau Merasakan kebajikan, artinya peserta didik bisa merasakan efek perbuatan baik yang dilakukannya sehingga tumbuh kecintaan untuk senantasa melakukan perbuatan baik dan secara tidak langsung membentuk sikap menghindari perbuatan jahat. dan yang Ketiga Active the good atau Melaksanakan kebajikan, artinya peserta didik bisa dan terbisaa berperilaku baik. Pada tahapan ini peserta didik dilatih untuk terbisaa berperilaku baik, tanpa terbisaa mengamalkan apa yang sudah diketahui atau dirasakan sebagai kebaikan maka tidak aka ada artinya. ${ }^{19}$

Tentunya menggunakan metode pembiasaan sebagai sarana pembentukan karakter religius peserta didik pasti memiliki kelebihan dan kekurangan. Kelebihan dalam menggunakan metode pembiasaan ini antara lain: 1) Metode Pembiasaan dalam sejarah merupakan metode yang paling

\footnotetext{
19 Aisyah M.Ali,Pendidikan Karakter:Konsep dan Implementasinya (Jakarta: Kencana, 2018)
}

Humanistika: Vol.8 No.1 2022 


\section{Impelementasi pembisaan membaca juz amma}

Untuk membentuk karakter religius peserta didik

efektif dalam membentuk karakter peserta didik. 2) Pembentukan kebiasaan yang dilakukan dapat menambah ketepatan dan kecepatan pelaksanaan. 3) Dapat menghemat tenaga dan waktu dengan baik. Sedangkan kekurangan yang dapat kita jumpai dalam menggunakan metode pembiasaan ini adalah bergantung pada seseorang yang mengajarinya. Teknik pembiasaan ini membutuhkan sikap dan karakter yang kompeten dari seseorang yang mengajarkannya. Dengan begitu, metode pembiasaan ini membutuhkan guru yang benar-benar menjadi teladan yang baik dalam memberikan nilai religi pada peserta didik. Selain itu kekurangannya adalah : 1) Pembiasaan secara berulang-ulang mudah membosankan. 2) Pembiasaan yang terlampau berat dapat menimbulkan perasaan benci pada peserta didik. 2) Membentuk kebiasaan yang kaku. ${ }^{20}$

Kemungkinan yang dapat ditingkatkan dalam pelaksanaan pembiasaan membaca Juz. Amma ini bisa dengan meningkatkan bacaan AlQur'an tidak hanya Juz. Amma saja melainkan peserta didik bisa membaca Al-Qur'an seperempat atau setengah juz setiap hari sehingga dalam beberapa bulan peserta didik bisa menghatamkan Al-Qur'an .

\section{Faktor Pendukung dan Penghambat}

Setiap pelaksaan pembiasaan pastinya terdapat faktor pendukung maupun pengahmbat seperti kendala dan permasalahan yang terjadi. Berkenaan dengan faktor pendukung dari pelaksanaan pembiasaan ini

20 Aisyah M.Ali,Pendidikan Karakter:Konsep dan Implementasinya (Jakarta: Kencana, 2018)

Humanistika: Vol.8 No.1 2022 
antara lain adalah peserta didik yang kebanyakan bereasal dari santi pondok pesantren dan mereka sangat bersemangat dalam melaksanakan pembiasaan memebaca Juz. Amma ini, mereka mengetahui faham bahwasanya dengan rutin membaca Al-Qur'an akan memberikan manfaat yang positif bagi mereka, yaitu menjadikan Al-Quran mudah dihafal dan bisa menjadi bekal bagi mereka kelak ketika bermasyarakat hal ini menjadi faktor pendukung yang amat sangat berguna bagi pelaksanaan dari pembiasaan ini. ${ }^{21}$

Selain faktor pendukung kami juga paparkan faktor penghambat seperti kendala dan permasalahan yang terjadi pada saat implementasi pembiasaan membaca Juг. Amma di MA Al-Kholafiyah Tekung Lumajang. Salah satu dari kendala yang kami temukan dating dari faktor peserta didikk sendiri, ada beberapa peserta didik yang belum lancar membaca Al-Qur'an , beberapa peserta didik ini notabenya berasal dari luar pesantren, artinya mereka tidak mondok di pesantren melainkan berangkat dari rumah. Karena karena faktor lingkungan, teman dan para peserta didik yang berasal dari luar pesantren itu tidak melakukan kegiatan mengaji di mushollah atau di rumahnya, mereka lebih senag dengan bermain gatget ataupun nongkrong dan bermain bersama teman sebayanya. Mereka cenderung minder ketika masih mengaji di musholla karena faktor usia sedangkan teman teman di mushollah adalah sepantaran anak-anak TK sampai SD. Alhasil ketika mereka tidak disibukkan dengan kegiatan mengaji di sekolah, mereka tidak akan pernah punya jam mengaji dalam kesehariannya di rumah. Berbeda, 


\section{Impelementasi pembisaan membaca juz amma}

\section{Untuk membentuk karakter religius peserta didik}

dengan peserta didik yang menetap di pondok pesantren mereka rata-rata bahkan seluruhnya sudah bisa bahkan bagus bacaan Al-Qur'an nya, karena kesehariannya di pesantren mereka tidak terlepas dari kegiatan mengaji.

Hal ini dikarenakan faktor lingkungan di rumah dengan demikian, peneliti bisa mengkaji bahwa keluarga berperan sangat penting bagi perkembangan kepribadian peserta didik, karena keluarga merupakan pendidik utama untuk peserta didik. Rasanya sia-sia jika di sekolah peserta didik dibiasakan melakukan kegiatan kegiatan yang baik dan positif tetapi di rumah mareka diabaikan. Memang benar, keluarga merupakan salah satu faktor yang mempengaruhi hasil belajar anak dan pengembangan karakter peserta didik. Keluarga dapat menjadi variabel pendukung dan bahkan dapat menjadi unsur penghambat bagi pengajar dalam mendidik peserta didik. dalam beberapa kasus, wali tidak peduli dengan kemampuan anak mereka untuk membaca Al-Qur'an, wali tidak fokus pada pentingnya memenuhi komitmen cinta kepada Allah swt. Ketiadaan perhatian orang tua membuat siswa tidak tertarik untuk mengikuti latihan-latihan yang ketat seperti yang dilakukan oleh para pendidik dan lembaga pendidikan.

Masalah lain juga kami jumpai di dalam kelas ketika pembacaan Jur. Amma berlangsung, beberapa peserta didik ada yang tidak mengikuti pembiasaan ini tidak membaca walaupun masih berada di dalam kelas, hal ini terjadi karena memang penjagaan peserta didik tidak begitu ketat, tidak 
ada dampingan dari guru kelas saat pembacaan berlangsung sehingga ada peserta didik yang leyeh leyeh tidak ikut membacanya. ${ }^{22}$

Setiap problem permasalahan yang terjadi dalam pengimplementasian memebca Juz Amma pastinya ada solusi untuk memperbaiki dan mengoptimalkannya, hal ini dilakukan agar tujuan dari pelaksanaan pembiasaan ini bisa terwujudkan dan tercapai. Solusi dari problem yang pertama adalah diadakannya belajar mengaji yaitu diadakannya seleksi terlebih dahulu dengan tes membaca Al-Qur'an, peserta didik yang lulus dalam tes tersebut tidak diwajibkan mengikuti kegiatan belajar mengaji resebut. Sebaliknya, peserta didik yang tidak lulus dalm tes itu maka wajib mengikuti kegiatan belajr mengaji, untuk belajar melancarkan dan membenarkan bacaan dalam segi tajwid, fasohan dan mkhorijul hurufnya. Kegiatan belajar mengaji ini di lakukan pada saat jam terakhir setelah pembelajaran peserta didik yang sudah lancar membaca Juz. Amma dalam kelas, tepi yang belum lancar membaca Al-Qur'an mereka belajar dengan guru pembimbing di kantor sekolah. Jadi mereka dibagi ke beberapa guru pembimbing untuk diajari membaca Al-Qur maskipun itu belajar dari pertama menggunakan iqra' atau qur'ani. ${ }^{23}$ berkaitan tentang ketertiban pelaksanaan hal ini dapat diatasi dengan pengkondisisn guru dalam kelas untuk memberikan motifasi agar agar siswa mengikuti kegitan tersebut dengan semangat dan rutin. guru selalu memberikan nasihat akan pentingnya ibadah. Guru juga mensosialisasikan penguatan terhadap peserta

\footnotetext{
22 Wawancara Bapak Supri (guru mapel \& pembimbing)

${ }^{23}$ Wawancara Bapak Supri (guru pembimbing)
}

Humanistika: Vol.8 No.1 2022 


\section{Impelementasi pembisaan membaca juz amma}

Untuk membentuk karakter religius peserta didik

didik tentang manfaat dan keutamaan serta dampak positif yang bisa diperoleh dari pembiasaan membaca Al-Quran.

\section{Implikasi pembisaaan membaca Juz Amma di MA Al-Kholafiyah \\ Pembiasaan membaca Juz. Amma yang telah dilakukan di MA Al-} Kholafiyah Tekung Lumajang memiliki hubungan yang sangat kuat dengan perubahan karakter peserta didik. Salah satu perkembangan yang dapat dirasakan oleh peserta didik adalah meningkatnya kapasitas peserta didik untuk membaca Al-Qur'an. Bahkan setelah ia membaca surat dalam alQur'an Juz Amma berulang kali, ternyata tidak sulit untuk mempertahankannya dan menghafalkannya. Sehingga ia lebih semangat lagi untuk melaksanakan hafalan yang telah diwajibkan oleh madrasah, mereka juga bersemangat dalam melakukan kegiatan ibadah lain yang berhubungan sengan surat pendek seperti melaksanakan sholat, peserta didik juga menjadi pribadi yang istiqomah dalam rutinitas membaca Al-Quran.

Implikasi bermakna keterlibatan, atau suatu hubungan, atau akibat yang berdampak secara langsung. Pada kegiatan pembiasaan membaca Jur. Amma yang dilaksanakan di MA- Al Kholafiyah Tekung tentu mempunya keterlibatan dan mempunyai dampak secara langsung pada transformasi kepribadian dan karakter peserta didik MA- Al Kholafiyah Tekung. Berdasarkan data sudah di deskripsikan di atas, metode pembiasaan membaca Jur. Amma yang telah diimplementasikan di MA Al- Kholafiyah tekung tersebut punya dampak yang besar bagi peserta didik. Seiring dengan berjalannya waktu, sikap dan kepribadian peserta didik yang semula kurang sesuai dengan nilai-nilai religius serta tujuan Madrasah Aliyah Al Kholafiyah Humanistika: Vol.8 No.1 2022 
Tekung, secara berangsur-angsur bisa berubah, tentunya menuju perubahan yang lebih baik (positif). Transformasi dari aspek ketrampilan, aspek sikap, maupun aspek karakter itu bisa diketahui dan bisa dirasakan oleh diri peserta didik sendiri, dan juga orang lain seperti teman-teman, guru, keluarga, masyarakat dan lain-lain.

Berkenaan dengan dampak metode pembiasaan membaca Juz Amma yang telah peneliti temukan pada proses penelitian ini telah didapatkan data debagai barikut: 1) Lebih terampil Dalam Membaca Alqur'an dan berjiwa Qur'ani. Berkenaan dengan trasformasi peserta didik dalam aspek ketrampilan, transformasi yang bisa dirasakan peserta didik yaitu peningkatan kemampuan peserta didik pada praktik membaca AlQur'an. Semula Peserta didik MA- Al Kholafiyah Tekung tidak lancar dalam bacaan Al-Qur'an kini bisa membaca Al-Qur'an dengan baik dan benar seuai kaidah tajwid. Terlebih lagi setelah peserta didik melksanakan pembiasaan membaca Juz, Amma ini setiap hatri dan istiqomah, mereka menjadi lebih mudah menghafal. Dan menjadikan mereka lebih semangat lagi untuk menghafal, yang mana siswa diwajibkan untuk menghafal Juz Amma. 2) Membentuk karakter istiqomah. Dengan mplementasi pembiasaan membaca Juz. Amma yang dilaksanakan seluruh peserta didik MA-Al Kholafiyah Tekung bisa memberikan transformasi kepada peserta didik, yaitu peningkatan kesadaran istiqomah peserta didik dalam beribadah kepada Allah SWT.

Dengan menerapkan pembiasaan ini peserta didik sudah melaksanakan tahapan-tahapan dalam membetuk karakter yang religious Humanistika: Vol.8 No.1 2022 


\section{Impelementasi pembisaan membaca juz amma}

Untuk membentuk karakter religius peserta didik

yaitu : 1) Mengetahui kebajikan (Knowing the good) Peserta didik mengetahui suatu hal yang baik dalam pelaksanaan pembiasaan memebaca Jur. Amma, bahwa dengan membaca Al-quran banyak menfaat dan pahal yang bias kita peroleh. 2) Merasakan kebajikan (Feeling the good) Peserta didik juga merasakan efek perbuatan baik yang dilakukan dengan pembiasaan membaca ini peserta didik semakin lancar dan semakin mudah dalam menghafal Juz. Amma. Hal ini menjadi efek yang positif dari pelaksanaan ini. 3) Melaksanakan kebajikan (Active the good) Peseta didik menjadi terbiasa dengn bacaan Al quran yang dibacanya setiap hari. Peserta didik dapat dan terbisaa melakukan kebajikan.

\section{Kesimpulan}

Implementasi pembiasaan membaca Jur. Amma merupakan suatu upaya untuk membentuk pribadi karakter religius peserta didik yang dilakukan di MA Al-Kholafiyah Tekung. Kegiatan pembiasaan ini dilakukan dan dilaksanakan setiap hari setelah jam pelajaran berakhir yaitu pada jam jam 11.30 sampai dengan 11.45. Rutinitas pembiasaan membaca Juz. Amma ini dilaksanakan di setiap kelas mualai dari kelas X sampai kelas XII baik itu IPA maupun IPS dan dipantau lagsung oleh guru.

Faktor pendukung dari pelaksanaan pembiasaan ini yaitu semangat dari diri pribadi peserta didik sendiri yang notabennya berasal dan menetap di pondok pesantren. Sedangkan faktor penghambat dari pelaksanaan pembiasaan ini yaitu adanya beberapa peserta didik yang masih belum bisa membaca Al-quran dengan lancar dan juga ketertiban saat melaksanakan Humanistika: Vol.8 No.1 2022 
pembiasaan membaca Jиг Amma. Namun untuk mengatasi beberapa masalah tersebut para guru di MA Al kholafiyah mengadakan kegiatan belajar mengaji bagi siswa yang belum lancar membaca Al-Qur'an dan juga guru memberikan motivasi si tentang pentingnya membaca Al-Qur'an dan terkait keutamaan membaca Al-Qur'an .

Pembiasaan membaca Juг, Amma yang telah dilakukan tersebut memberikan pengaruh/implikasi yang besar pada peserta didik. Seiring berjalannya waktu sikap dan karakter peserta didik menjadi lebih baik implikasi pembiasaan membaca Juz Amma ini yaitu meningkatkan keterampilan membaca $\mathrm{Al}$-Qur'an dan membuat siswa berjiwa Qurani serta meningkatkan kesadaran Istiqomah. Hal tersebut menjadikan peserta didik di MA Al kholafiyah telah melaksanakan tahapan-tahapan dalam membentuk karakter religius yaitu mengetahui kebajikan, merasakan kebajikan, dan melaksanakan kebajikan. 


\section{Impelementasi pembisaan membaca juz amma}

Untuk membentuk karakter religius peserta didik

\section{DAFTAR PUSTAKA}

A.Rodli Makmun.2014.Pembentukan Karakter Berbasis Pendidikan Pesantren (Studi Di Pondok Pesantren Tradisional Dan Modern Di Kab. Ponorogo).Ponorogo: Stain Ponorogo Press. Diakses dari https://jurnal.iainponorogo.ac.id/ [15 september 2021]

Abdul Majid dan Andayani.2013. Pendidikan Karakter PrespektifIslam.Bandung: PT Rosda Karya

Aisyah M. Ali.2013. Pendidikan Karakter: Konsep dan Implementasinya.Jakarta:Kencana, 2018.

Akhmad Muhaimin Azzet. 2013.Urgensi Pendidikan Karakter Di Indonesia: Revitalisasi Pendidikan Karakter Terhadap Keberhasilan Dan Kemajuan Bangsa.Jogjakarta: Ar-Ruzz Media

Amirulloh Syarbini.2014.Model Pendidikan Karakter dalam Keluarga. Jakarta: Elex Media Komputindo.

Dokumen Visi Misi Madrasah Al-Kholafiyah Tekung Lumajang

E. Mulyasa.2011.Manajemen Pendidikan Karakter .Jakarta: Bumi Aksara.

Moh Ahsanulkhaq.2019.Membentuk Karakter Religius Peserta Didik Melalui Metode Pembisaaan.Vol. 2 No. 1. Jurnal Prakarsa Paedagogia. Diakses dari https://jurnal.umk.ac.id [15 September 2021)

Ngainun Na'im.2012.Character Building: Optimalisasi Peran Pendidikan Dalam Pengembangan Ilmu \& Pembentukan Krakter Bangsa.Jogjakarta: Ar-Ruzz Media

Nursalam, et al.2020.Model Pendidikean Karakter.Serang: CV AA Rizky

Humanistika: Vol.8 No.1 2022 
Ridwan Abdullah Sani dan Muhammad Kadri. 2016. Pendidikan Karakter. Jakarta: Bumi Aksara

Rosniati Hakim.2014.Pembentukan Karakter Peserta Didik melalui Pendidikan Berbasis Al-Qur'an.Vol. 4 No.2. Jurnal Pendidikan Karakter. Diakses Dari https://journal.uny.ac.id/ [15 September 2021]

Taufiqurrahman dan Siti Musawwamah.2017.Pembentukan Karakter Mahasiswa dalam Sistem Pendidikan Tinggi Islam.Pamekasan:IKAPI.

Undang-Undang Republik Indonesia. 2006. Nomor 20 Tahun 2003 Tentang SISDIKNAS Bandung:Citra Umbara 